\title{
Perikardiális folyadék és egy ritka betegség: csapatmunkában az erö
}

\author{
Illés Blanka', Ágoston Gergely², Morvay Zita³ ${ }^{3}$ Séllei Ágnes³ , Janáky Márta4, \\ Kovács Lászlós, Varga Albert²
}

\author{
${ }^{1}$ Szegedi Tudományegyetem, Általános Orvostudományi Kar, ${ }^{1} I I$. számú Belgyógyászati Klinika és Kardiológiai \\ Központ, ${ }^{2}$ Családorvosi Intézet, ${ }^{3}$ Radiológiai Klinika, ${ }^{4}$ Szemészeti Klinika, ${ }^{5}$ Reumatológiai és Immunológiai \\ Klinika, Szeged
}

Levelezési cím: Dr. Illés Blanka, Szegedi Tudományegyetem, Általános Orvostudományi Kar, Il-es számú Belgyógyászati Klinika és Kardiológiai Központ, Semmelweis utca 8., E-mail: illesblanka@gmail.com

\begin{abstract}
Az óriássejtes arteritis tünetei gyakran nem specifikusak, a perikardiális fluidum pedig egy kifejezetten ritka manifesztációja ennek a betegségnek. Az esettanulmányunkban bemutatott beteg kivizsgálása perikardiális fluidum miatt kezdődött, majd a vizsgálatok a beteg korábbi tüneteit is magyarázó óriássejtes arteritis diagnózisát igazolták. Az adekvát terápia bevezetését követően a beteg panaszai fokozatosan enyhültek, a perikardiális folyadék pedig megszünt.
\end{abstract}

Kulcsszavak: perikardiális folyadék, mellkasi fájdalom, látászavar, vasculitis

\section{Pericardial effusion associated to a rare disease - An interdisciplinary challenge}

The symptoms of giant cell arteritis are often nonspecific and pericardial effusion is a rare manifestation of the disease. The case report describes a patient presented with newly diagnosed pericardial effusion. After the detailed investigation the final diagnosis was giant cell arteritis, which explained the patient's earlier symptoms. After the initiating of adequate therapy, the patient's symptoms rapidly decreased and the pericardial effusion disappeared.

Keywords: pericardial effusion, chest pain, visual disturbance, vasculitis

\section{Esetbemutatás}

A 68 éves nőbeteg kivizsgálása egy éve fennálló, minimális terhelésre kialakuló dyspnoe és szédülés miatt kezdődött, amelyet kétoldali alsó végtagi ödéma és több mint $30 \mathrm{~kg}$ fogyás kísért. A felvételét megelőző évben gyakran alakult ki terheléstöl független, tompa mellkasi fájdalom. Diffúz mozgásszervi panaszok szintén gyakoriak voltak arthritisre utaló jelek nélkül. 26 évvel korábban a beteg elmondása szerint agyvelőgyulladása zajlott, azóta gyakran alakult ki bal oldali fejfájás, amely osztályos felvételekor nem állt fenn. Láz, hidegrázás, éjszakai izzadás nem szerepelt a panaszok között.

Egy évvel felvételét megelőzően nehézlégzés, anginiform panaszok miatt sürgősségi betegellátó osztályon mellkas CT-angiográfia készült, amely az aorta ascendens falában intramuralis haematomát írt le (1. ábra); pulmonalis embóliára, pericarditisre utaló eltérés nem került leírásra. Néhány hónappal később rekedtség jelentkezett, amelynek hátterében fül-orr-gégészeti szakvizsgálat bal oldali nervus recurrens paresist véleményezett, amelyet az intramuralis haematoma következményének tartottak; endoszkópos arytenoid lateropexia történt.

A beteg korábbi betegségei között hipertónia, 2-es típusú diabetes mellitus és kétoldali katarakta szerepelt. A katarakta mütét ellenére a beteg bal szemére nem látott. Osztályunkra érkezésekor testsúlya 76 kg volt. Fizikális vizsgálat során kisfokú lábszárödéma volt tapintható és a mitralis billentyű felett 2/6-os szisztolés zörejt hallottunk. A nyugalmi EKG és a mellkasröntgen nem mutatott kórjelző eltérést, a laborvizsgálatok paraméterei a vörösvértest-süllyedés $(52 \mathrm{~mm} / \mathrm{h})$ kivételével nem utaltak kóros folyamatra (kreatinin $45 \mu \mathrm{mol} / \mathrm{l}$, eGFR >60 ml/min/tf, TSH 1,26 mlU/l, CRP 2,3 mg/l). A beteg panaszait a hatperces sétateszt segítségével sikerült objektivizálni, amely során csupán 120 métert 


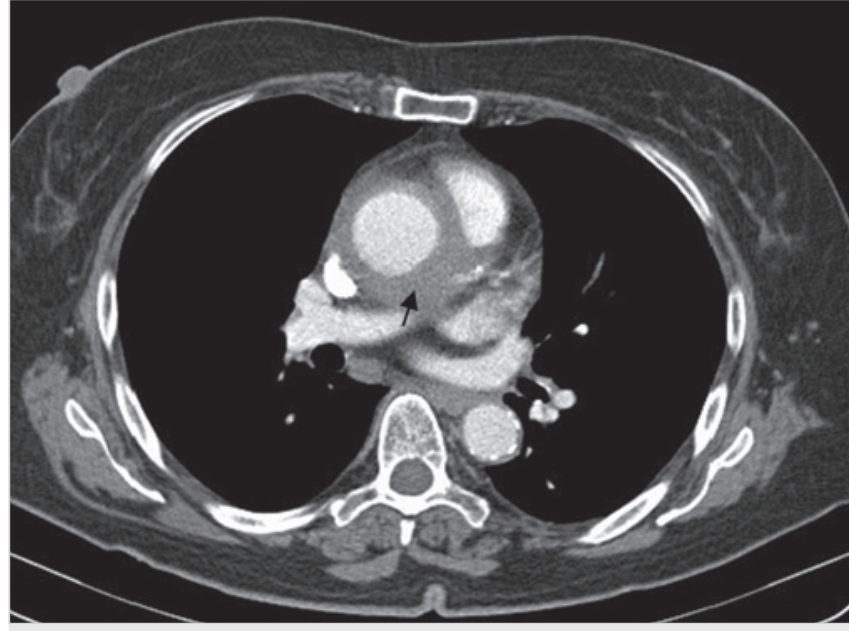

1. ÁBRA. Intramurális haematoma az aorta falában (nyíl) mellkas CT-angiográfiával

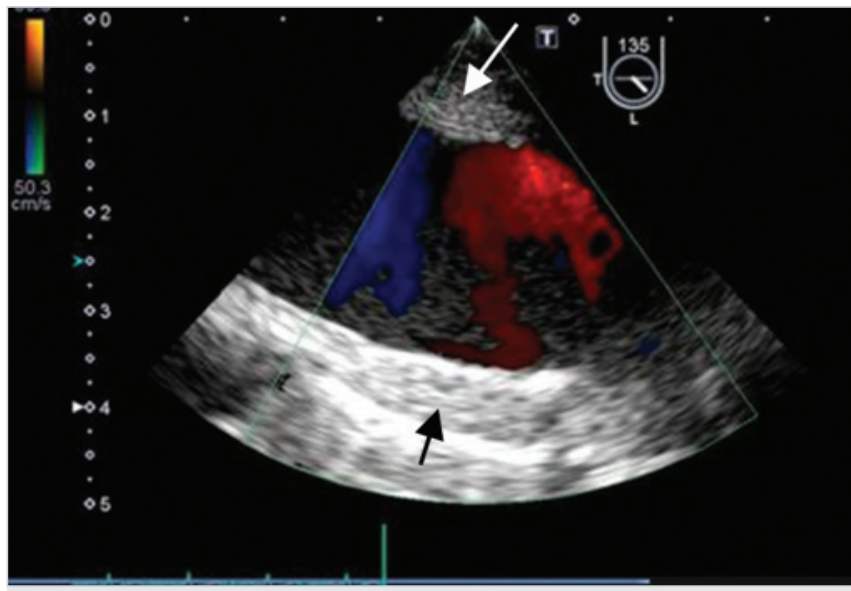

2. ÁBRA. Transoesophageális echokardiográfiás vizsgálattal az aortaív megvastagodott intimája látható (nyilak)

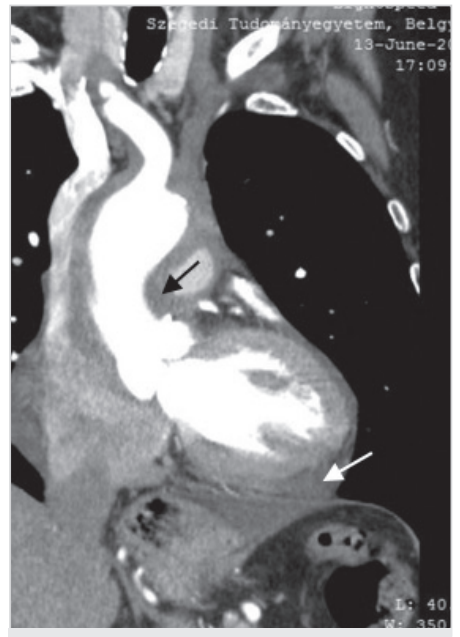

3. ÁBRA. Az aorta ascendens és ív falának koncentrikus megvastagodása (fekete nyíl), kisfokú perikardiális folyadékgyülem mellett (fehér nyíl), mellkas CT-angiográfiával tudott megtenni, miközben oxigén-szaturációja 97\%-ról 82\%-ra esett. Transthoracalis echokardiográfiás vizsgálat során tágabb aorta ascendens, valamint a jobb kamra és a szívcsúcs körül 10 mm-es perikardiális fluidum volt látható, a constrictiv pericarditist a Dopplerultrahangos mérések kizárták (E-hullám légzési variációja: $60 \mathrm{~cm} / \mathrm{s}$ - $67 \mathrm{~cm} / \mathrm{s}$; laterális $\mathrm{E}_{\mathrm{a}}: 9 \mathrm{~cm} / \mathrm{s}$, septalis $\mathrm{E}_{\mathrm{a}}$ $4 \mathrm{~cm} / \mathrm{s}$ ). Az ismeretlen eredetü perikardiális folyadékgyülem és a korábban leírt intramuralis

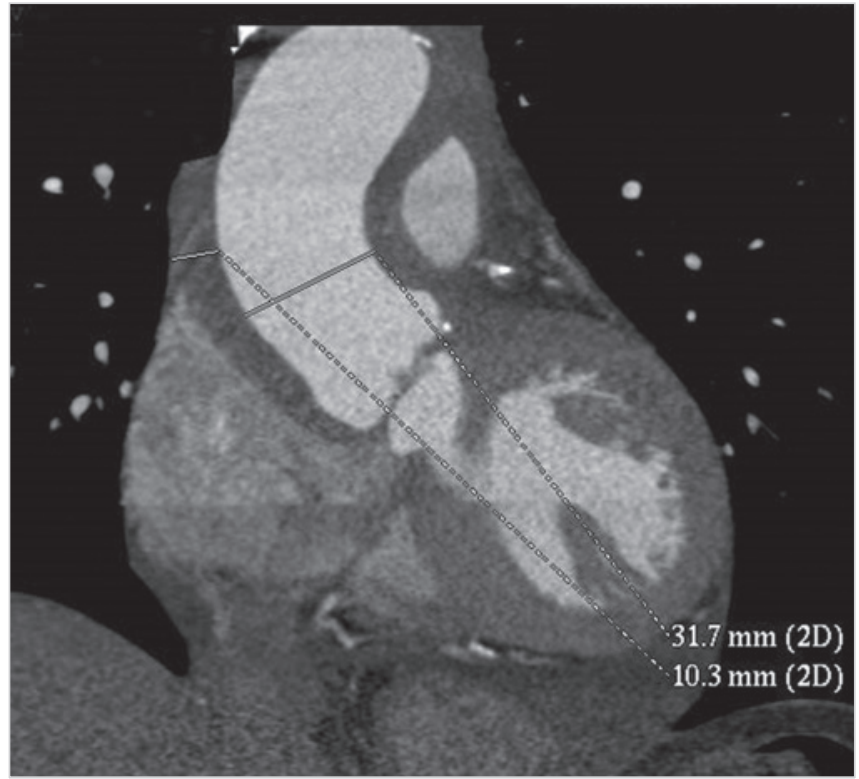

4. ÁBRA. Szív-CT vizsgálattal látható, hogy az aorta ascendens falának vastagsága meghaladja az $1 \mathrm{~cm}-\mathrm{t}$

haematoma miatt transoesophagealis echokardiográfia is készült, amely körkörösen megvastagodott falú aorta ascendenst $(9 \mathrm{~mm})$ és aortaívet $(5 \mathrm{~mm})$ írt le az aorta descendens érintettsége nélkül (2. ábra). A fenti leleteket az ismételten elvégzett mellkas CT-angiográfia is megerősítette; a korábban leírt intramuralis haematoma nem volt látható (3. ábra). A laboratóriumi autoimmun panel ANCA-pozitivitást mutattak kifejezetten emelkedett antiproteináz-3 szinttel (>200 U/ml) és jelzetten emelkedett rheumatoid faktor szintekkel (RFIgM 149 IU/ml, RFlgG 9 IU/ml). Az egyéb vizsgált antitestszintek (ANA, SS-A, SS-B, anti-Scl-70, anti-Jo1, anti-RNP-70, anti-Sm, anticentromér) negatívnak bizonyultak. Te-

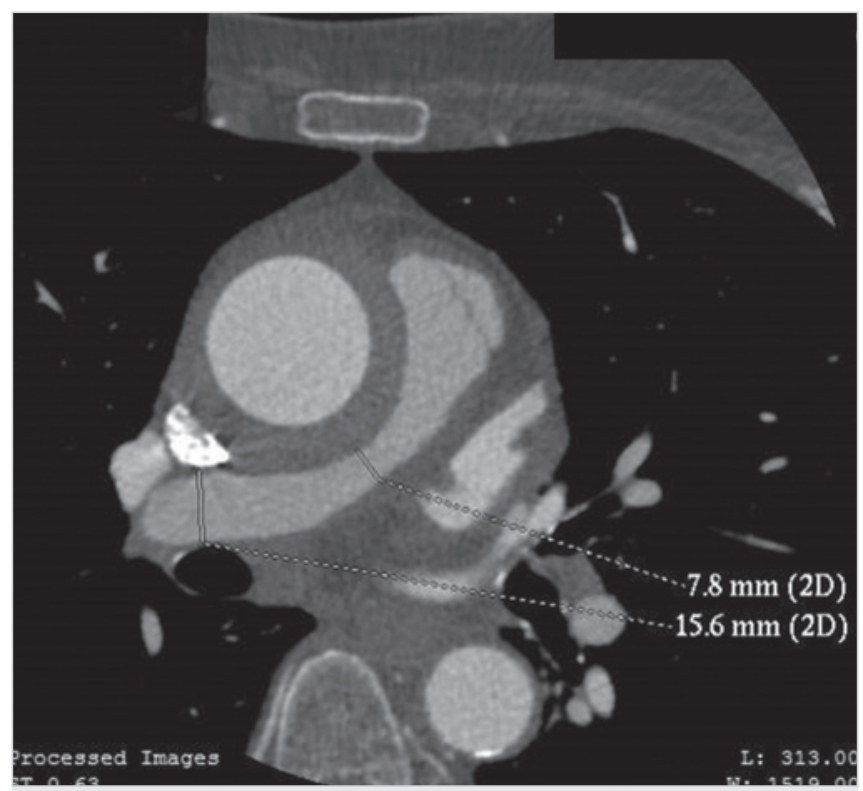

5. ÁBRA. Vasculitis által okozott megvastagodás az aorta és a truncus pulmonalis falában, szív-CT vizsgálattal 


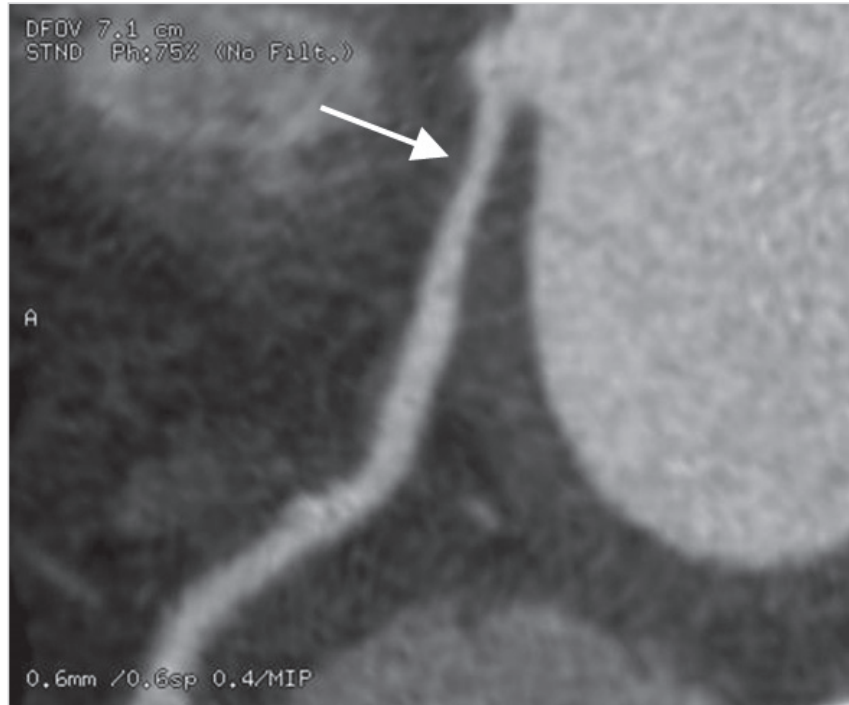

6. ÁBRA. A szív-CT vizsgálat a jobb koronárián enyhe szűkületét mutatja (nyíl), amelynek hátterében az aorta falának megvastagodása áll

kintettel arra, hogy az eddigi eredmények vasculitisre utaltak, további képalkotó vizsgálatok történtek a gyulladásos folyamat kiterjedésének megítélése céljából. A hasi Doppler-ultrahang abdominalis érintettséget nem igazolt. A szív-CT $10 \mathrm{~mm}$ vastag koncentrikus aortafal-megvastagodást írt le, amely enyhe fokú szükületet okozott a jobb koronária-eredésében (6. ábra), valamint a truncus pulmonalis és mindkét arteria pulmonalis is érintett volt. A bal oldali arteria pulmonalison 53\%-os szükületet detektáltunk, amelyet főként a megvastagodott falú aorta benyomata okozott (4. és 5 . ábra). A

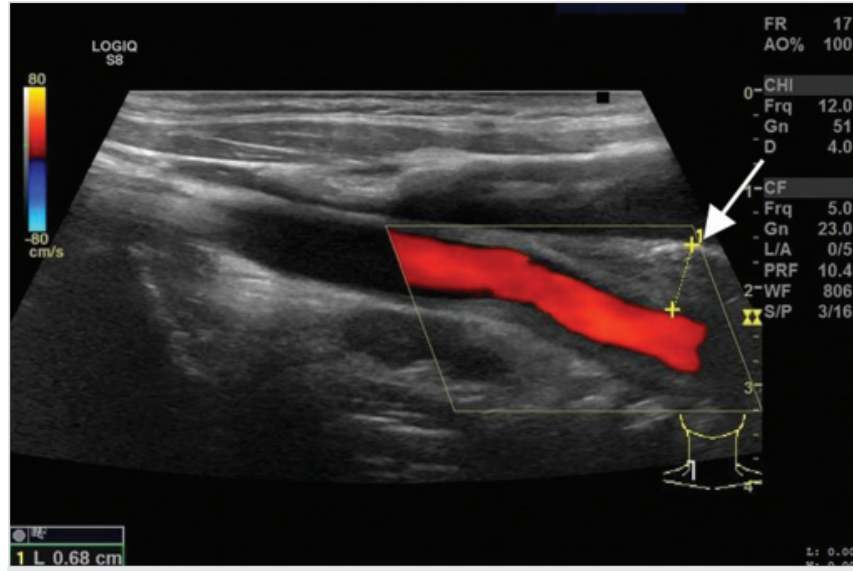

7. ÁBRA. A jobb oldali arteria carotis communis gyulladására utaló falmegvastagodása (nyíl), nyaki erek Doppler-vizsgálatával

carotis Doppler-ultrahang a jobb arteria carotis communis tunica media gyulladásra utaló körülírt megvastagodását írta le, a bal oldali nyaki érszakaszt a folyamat lényegesen kisebb mértékben érintette (7. ábra). Tekintettel a korábbi szemmütétek ellenére fennálló bal oldali vakságra, szemészeti szakvizsgálat is történt, amely a szemfenék-vizsgálattal mindkét oldalon fakóbb vakfoltot észlelt, a vizuálisan kiváltott válasz a bal oldalon csökkent volt (8. ábra), a mintázott elektroretinográfia pedig a jobb oldalon normál, míg a bal oldalon csak zajszintű választ tudott kiváltani (9. ábra). A szemészeti vizsgálatok a bal oldali anterior iszkémiás opticus neuropathia diagnózisát igazolták. Ezen szemészeti szövődmény, a nagyér-érintettség, a beteg
Jobb szem

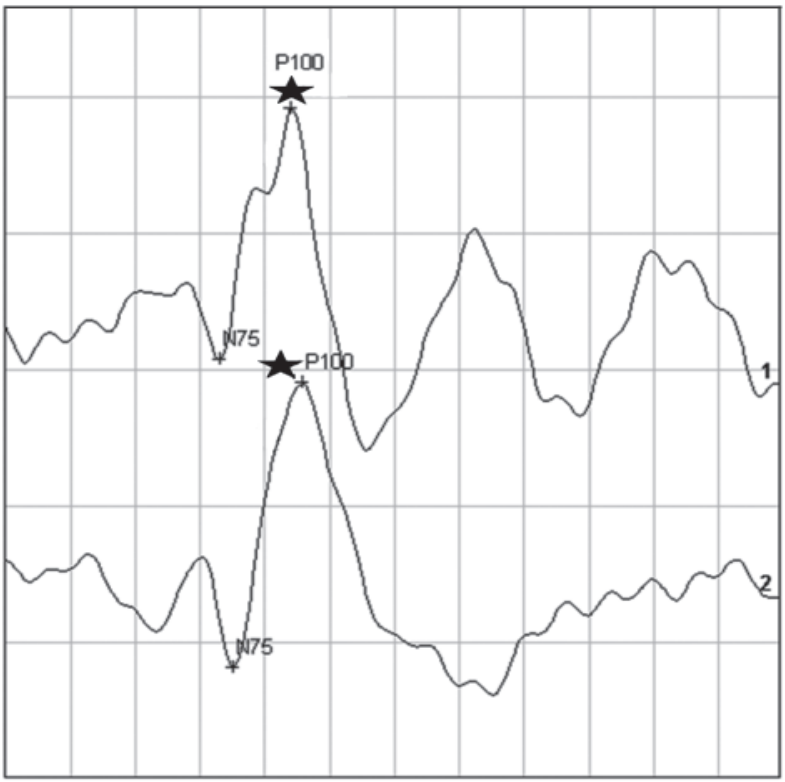

Bal szem

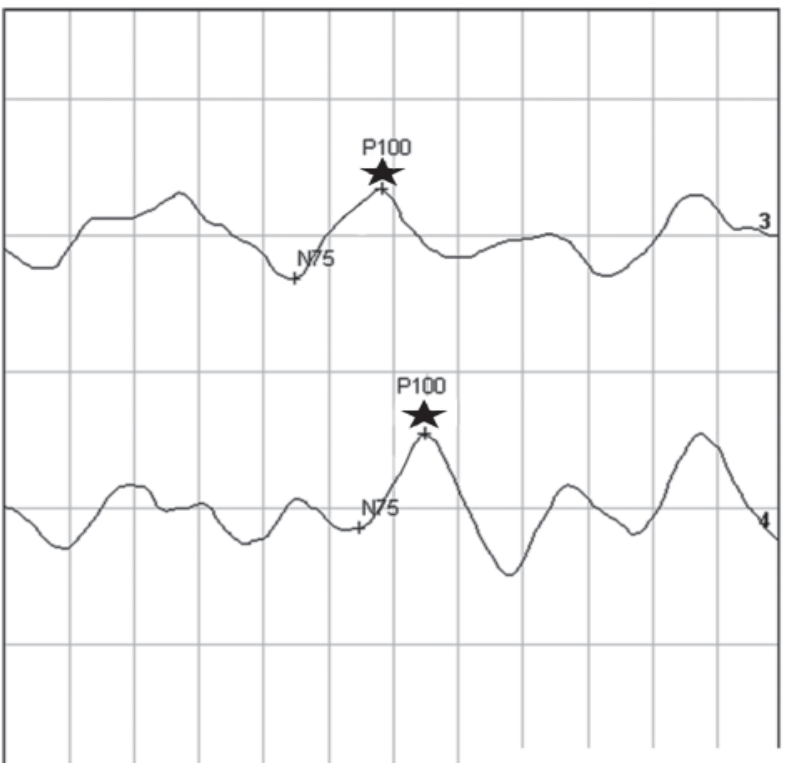

$25 \mathrm{~ms} / \mathrm{div}$

8. ÁBRA. Normál jobb oldali vizuálisan kiváltott válasz mellett a bal szemen jelentősen csökkent értékek láthatók. A P100-hullámot csillag jelzi 


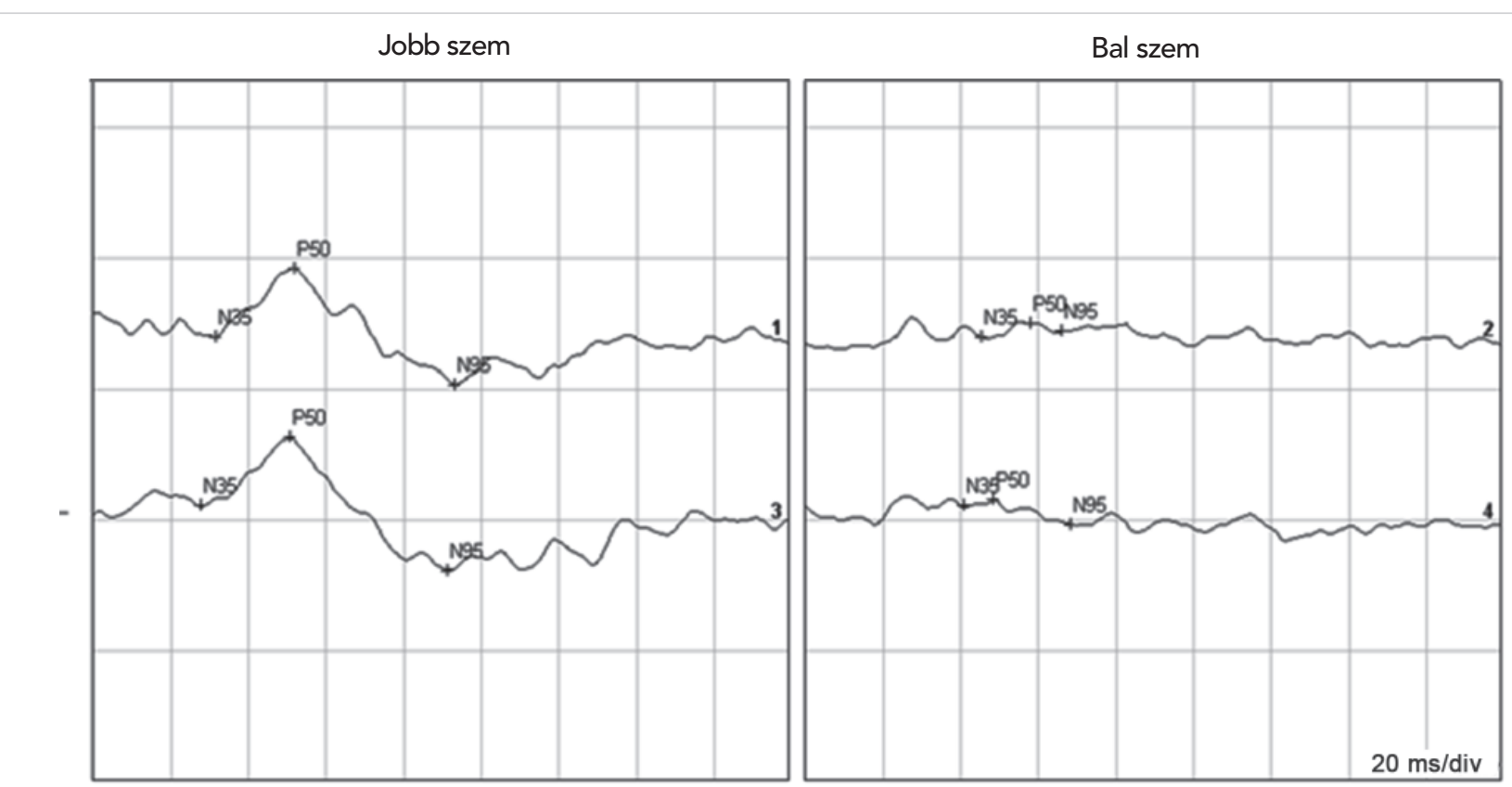

9. ÁBRA. A mintázott retinográfia során a bal szemnél mért értékek alig emelkednek ki a zajszintből. (A regisztátumon jelzett hullámok sorrendben: N35, N50, N95.)

kora, a polyangitis granulomatosára (korábban Wegener-granulomatosis) jellegzetes tünetek hiánya (felsöés alsólégúti tünetek, veseérintettség) együttesen pedig arteritis temporalis fönnállását támogatta. Eddigi terápiája (pantoprazol, perindopril, amlodipin, rilmenidin, bisoprolol, glimepirid, sertralin, alprazolam, vinpocetin, furosemid, brinsolamidos-timololos szemcsepp, dexametazonos szemcsepp) mellé $32 \mathrm{mg}$ methylprednisolon- és $5 \mathrm{mg}$ methotrexát terápia indult folsav-, kálium-klorid- és cholecalciferol-kiegészítéssel, amelynek eredményeként a beteg panaszai fokozatosan csökkentek. Háromhónapos kezelést követö kontrollvizsgálaton perikardiális fluidumot már nem észleltünk, a beteg testsúlya elmondása szerint pár kilogrammot nőtt, mellkasi fájdalma szűnt, terhelhetősége javult. Ezt követően a methylprednisolon dózisát $4 \mathrm{mg}$-ra sikerült csökkenteni, emellé heti $15 \mathrm{mg}$ methotrexátot kapott. Kilenc hónapos további immunszuppresszív terápiát követő transoesophagealis echokardiográfián pedig az aorta fala $3 \mathrm{~mm}$-rel vékonyabbnak mutatkozott, mint a kezelést megelőzően.

\section{Megbeszélés}

Az óriássejtes arteritis vagy másnéven arteritis temporalis a nagy és közepes erek krónikus, gyakran granulomatosus gyulladása, amely föként az aorta cranialis ágait érinti. Jellemzően 50 évnél idősebb korban jelentkezik (1). A leggyakoribb tünetek közé tartozik az újkeletű fejfájás, különböző látászavarok, polymyalgia rheumatica, állkapocs-claudicatio, valamint az emelkedett vörösvértest-süllyedés és CRP-szint. Az arteria pulmonalis vagy az aorta falának jelentős megvastagodása bal oldali nervus recurrens paresishez vezethet, azonban ez rendkívül ritka szövődménye az óriássejtes arteritisnek (2). A diagnosztika alapját az arteria temporalis biopszia képezi, de ez fals negatív eredményt hozhat az esetek $15-40 \%$-ában (3). A fals negatív eredmény oka elsősorban az, hogy a gyulladás a mintavétel időpontjában nem érinti a temporalis artériát, vagy a gyulladás nem folytonosan terjedő jellegéből adódóan a mintavétel történhet érintetlen érszakaszból is (4).

Az általunk leírt esettanulmányban a diagnosztikai nehézséget az óriássejtes arteritis atípusos megjelenése okozta. Az intramuralis haematoma, amelyet a panaszok kezdetén készített sürgősségi mellkas CT-vizsgálaton írtak le, lehetett valódi haematoma a beteg meglévő vaszkuláris rizikófaktorai miatt, lehetett az aorta falának granulomatosus megvastagodása (ami a nagyér-vasculitisek jellemzője), de akár a vasa vasorum vasculitise is, ami - többek között - polyarteritis nodosára utalhat. A helyes diagnózis felállítását tovább bonyolítja, hogy az intramuralis haematoma és a vasculitis radiológiai elkülönítése egyes esetekben nem egyszerü.

Az érgyulladás kiterjedése mind Takayasu-, mind óriássejtes arteritisre utalhatott, bár a panaszok kezdetekor betegünk már jóval idősebb volt 50 évnél, ami a Takayasu-arteritis fennállásának valószínüségét lényegesen csökkentette. Az autoimmun szerológia kisér-vasculitis fennállását támogatta, bár a klinikai kép egyértelműen nagyér-vasculitis mellett szólt. A diagnózishoz hiányzó utolsó információt a szemészeti vizsgálat szolgáltatta: az arteritises eredetủ anterior iszkémiás opticus neuropathia jellemzően az óriássejtes arteritis egyik leggyakoribb szövődménye (5). 
A kardiális érintettség óriássejtes arteritisben viszonylag ritka, általában coronaritisként vagy miokardiális infarktusként jelentkezik (6). Perikardiális folyadékgyülem társulása irodalmi ritkaságnak számít ebben a betegségben. Pontos prevalenciája ismeretlen, azonban egy kis betegszámú $(n=114)$, retrospektív vizsgálat az óriássejtes arteritissel diagnosztizált betegek csak 4\%-ában írt le perikardiális fluidumot, a betegek 1\%-ában ez volt az arteritis első tünete (7). A perikardiális fluidum ezekben az esetekben panaszt általában nem okoz, azonban a részletes kivizsgálás révén elvezethet a végső diagnózishoz és a specifikus terápiához, amellyel megelőzhető egy potenciálisan halálos szövődmény, az aorta aneurizma ruptura.

Irodalom

1. Jennette JC, Falk RJ, Bacon PA, et al. 2012 revised International Chapel Hill Consensus Conference Nomenclature of Vasculitides.
Arthritis and rheumatism 2013; 65(1): 1-11. https://doi.org/10.1002/art.37715

2. Edrees A. Ortner's syndrome as a presenting feature of giant cell arteritis. Rheumatology international 2012; 32(12): 4035-4036.

https://doi.org/10.1007/s00296-010-1533-z

3. Chong EW, Robertson AJ. Is temporal artery biopsy a worthwhile procedure? ANZ journal of surgery 2005; 75(6): 388-391.

https://doi.org/10.1111/j.1445-2197.2005.03399.x

4. Poller DN, van Wyk Q, Jeffrey MJ. The importance of skip lesions in temporal arteritis. Journal of clinical pathology 2000; 53(2): 137-139. https://doi.org/10.1136/jcp.53.2.137

5. Biousse V, Newman NJ. Ischemic Optic Neuropathies. The New England journal of medicine 2015; 372(25): 2428-2436.

https://doi.org/10.1056/NEJMra1413352.

6. Knockaert DC. Cardiac involvement in systemic inflammatory diseases. European heart journal 2007; 28(15): 1797-1804. https://doi.org/10.1093/eurheartj/ehm193

7. Zenone T, Puget M. Pericardial effusion and giant cell arteritis Rheumatology international 2014; 34(10): 1465-1469.

https://doi.org/10.1007/s00296-014-2958-6

\section{Kommentár}

Tisztelt Szerkesztőség, tisztelt dr. Berek Krisztina!

A Cardiologia Hungarica 2016; 46: (1) 14-16. számában megjelent Rapidan progrediáló restriktív cardiomyopathia című esetismertetéshez szeretnék kiegészítést írni.

Az esetismertetésben szereplő betegnek minden bizonnyal chloroquin cardiomyopathiája volt. Ez egy ritka entitás, tudomásom szerint mindössze néhány tucatnyi esetről számol be az irodalom.

Jellemzői: vezetési zavarok, gyakran III ${ }^{\circ} \mathrm{AV}$-blokk, ami sokszor megelőzi a szívizom-hypertrophia és restriktív cardiomyopathia kialakulását. A kumulatív dózis nem mutat szoros összefüggést a kórkép kialakulásával.

Fénymikroszkóposan vakuolás degeneráció jellemzi, így hasonlít egyéb eredetủ szívizombántalomhoz, pl. szteroid-indukálta, vagy vírusos myocarditishez. Elektronmikroszkóppal zárványtestek láthatóak benne (a chloroquin a lysosomák müködésében okoz zavart), amelyek lehetnek lamellarisak (nem teljesen specifikusak, megjelenhet tárolási betegségben, vagy amiodaron szedésekor is) és ún. curvilinearisak (szabálytalan könnycseppre vagy babra hasonlító), ezek viszont a cytoplasma vakuolizáltságával együtt specifikusak és diagnosztikusak.

A cikkben felvetett Fábry-kór hasonló fénymikroszkópos képet mutat, de a beteg anamnézisében szereplő 10 éves Delagil-kezelés, a tünetek megjelenésének sorrendje és típusa (szívblokk, majd súlyos restriktív CMP), és a szövettan együttesen egyértelműen a Delagil kóroki szerepére utalnak.

A beteg első jeletkezésekor észlelt szívblokk diagnosztizálását követően a Delagil-kezelés elhagyása jótékony talán lehetett volna, bár ezt nem lehet biztosan tudni.

Érdemes lenne a reumatológusok és kardiológusok figyelmét felhívni a kórkép létezésére, különösen most, hogy a Delagil SLE-s betegek körében reneszánszát kezdi élni.

Üdvözlettel,

Czine Zsigmond 